\title{
Cross-species screening of microsatellite markers for individual identification of snow petrel Pagodroma nivea and Wilson's storm petrel Oceanites oceanicus in Antarctica
} \author{
Samrat Mondol Corresp. 2 \\ 1 Endangered Species Management, Wildlife Institute of India, Dehradun, Uttarakhand, India \\ 2 Animal Ecology and Conservation Biology, Wildlife Institute of India, Dehradun, Uttarakhand, India \\ 3 Director, Wildlife Institute of India, Dehradun, Uttarakhand, India \\ Corresponding Author: Samrat Mondol \\ Email address: samrat@wii.gov.in
}

Anant Pande ${ }^{1}$, Nidhi Rawat ${ }^{2}$, Kuppusamy Sivakumar ${ }^{1}$, Sambandan Sathyakumar ${ }^{1}$, Vinod B Mathur ${ }^{3}$,

Seabirds are important indicators of marine ecosystems health. Species within the order Procellariiformes are most abundant seabird species group distributed from warm tropical to cold temperate regions including Antarctica. There is a paucity of information on basic biology of pelagic seabird species nesting on the Antarctic continents and long-term studies are required to gather data on their population demography, genetics and other ecological parameters. Under the 'Biology and Environmental Sciences' component of the Indian Antarctic programme, long-term monitoring of Antarctic biodiversity is being conducted. In this paper, we describe results of cross-species screening of a panel of 12 and 10 microsatellite markers in two relatively little studied seabird species in Antarctica, the snow petrel Pagodroma nivea and the Wilson's storm petrel Oceanites oceanicus, respectively. These loci showed high amplification success and moderate levels of polymorphism in snow petrel (mean no. of alleles 7.08 \pm 3.01 and mean observed heterozygosity $0.35 \pm 0.23$ ), but low polymorphism in Wilson's storm petrel (mean no. of alleles $3.9 \pm 1.3$ and mean observed heterozygosity $0.28 \pm 0.18$ ). The results demonstrate that these panels can unambiguously identify individuals of both species (cumulative PID $_{\text {sibs }}$ for snow petrel is $3.7 \times 10^{-03}$ and Wilson's storm petrel is $1.9 \times 10^{-02}$ ) from field-collected samples. This work forms a baseline for undertaking long-term genetic research of these Antarctic seabird species and provides critical insights into their population genetics. 
1 Cross-species screening of microsatellite markers for individual identification of snow petrel

2 Pagodroma nivea and Wilson's storm petrel Oceanites oceanicus in Antarctica

3

4 Running head: Individual identification of two Antarctic seabird species

5

6 Anant Pande ${ }^{* 1}$, Nidhi Rawat ${ }^{* 2}$, Kuppusamy Sivakumar ${ }^{1}$, Sambandan Sathyakumar', Vinod B.

7 Mathur $^{3}$, Samrat Mondol ${ }^{\# 2}$

$8{ }^{1}$ Endangered Species Management, Wildlife Institute of India, Dehradun, Uttarakhand, India

$9{ }^{2}$ Animal Ecology and Conservation Biology, Wildlife Institute of India, Dehradun, Uttarakhand, 10 India

11 32Director, Wildlife Institute of India, Dehradun, Uttarakhand, India

12

*equal contribution

\# Corresponding author: Samrat Mondol, Assistant Professor, Animal Ecology and Conservation

Biology, Wildlife Institute of India, Dehradun, Uttarakhand, India,

Email: samrat@wii.gov.in 
ABSTRACT

Seabirds are important indicators of marine ecosystems health. Species within the order

Procellariiformes are most abundant seabird species group distributed from warm tropical to cold temperate regions including Antarctica. There is a paucity of information on basic biology of pelagic seabird species nesting on the Antarctic continents and long-term studies are required to gather data on their population demography, genetics and other ecological parameters. Under the

'Biology and Environmental Sciences' component of the Indian Antarctic programme, long-term monitoring of Antarctic biodiversity is being conducted. In this paper, we describe results of crossspecies screening of a panel of 12 and 10 microsatellite markers in two relatively little studied seabird species in Antarctica, the snow petrel Pagodroma nivea and the Wilson's storm petrel Oceanites oceanicus, respectively. These loci showed high amplification success and moderate levels of polymorphism in snow petrel (mean no. of alleles $7.08 \pm 3.01$ and mean observed heterozygosity $0.35 \pm 0.23$ ), but low polymorphism in Wilson's storm petrel (mean no. of alleles $3.9 \pm 1.3$ and mean observed heterozygosity $0.28 \pm 0.18$ ). The results demonstrate that these panels can unambiguously identify individuals of both species (cumulative PID $_{\text {sibs }}$ for snow petrel is 3.7 critical insights into their population genetics. 


\section{INTRODUCTION}

52

53

54

55

56

57

58

59

60

61

62

As top predators, seabirds maintain structure of marine food webs, regulate island and marine ecosystem processes and act as indicators of marine ecosystem health (Lascelles et al., 2012; Paleczny et al., 2015). Their ability to fly over large distances, extreme life history strategies (monogamy, slow reproduction, late sexual maturity), natal philopatry, high visibility and dependence on land for breeding makes it essential to conduct long-term population level studies (Piatt, Sydeman \& Wiese, 2007) for better understanding of their biology. Recent studies focusing on seabird population monitoring have highlighted the threatened status of seabirds across the globe (Croxall et al., 2012), especially in the Southern Ocean where seabird populations have declined substantially over last few decades (Paleczny et al., 2015). This has led to interdisciplinary approaches to understand seabird population dynamics to aid their conservation and management across their distribution range (Croxall et al., 2012; Taylor and Friesen, 2012).

Seabirds within the order Procellariiformes comprising petrels, shearwaters, albatrosses, storm petrels and diving petrels represent one of the most widely distributed and abundant avifauna (Warham, 1996). Despite their broad distribution and large population sizes, long-term ecological and genetic data exists for few of these species across the globe. In addition to several ecological studies on Procellariiforms (Croxall et al. 2012), some recent studies have used genetic data to address important biological parameters such as relatedness, population structure, past population demography (e.g. see Gómez-Díaz, González-Solís \& Peinado, 2009 for Cory's shearwater; Welch et al., 2012 for Hawaiian petrel) for species distributed in tropical and Arctic marine ecosystems. Research on the biology of Procellariiforms is relatively limited in the Southern Ocean ecosystem, especially in Antarctica because of its remoteness and associated logistical difficulties. Despite 
73 site-specific monitoring of some Procellariiforms on sub-Antarctic islands (e.g. Brown et al., 2015

74 for giant petrels; Quillfeldt et al., 2017 for Antarctic prion, thin-billed prion and blue petrel) and

75 Antarctic coast (e.g. Barbraud \& Weimerskirch, 2001 for snow petrel; Barbraud \& Weimerskirch,

762006 for multiple species; Techow et al., 2010 for giant petrels), long-term ecological as well as

77 genetic research is sparse. Nunn and Stanley (1998) reported the phylogenetic relationships among

78 Procellariiforms using a neighbour-joining approach, but within each family, detailed population

79 genetic information is lacking. Prior studies have used Restriction Fragment Length

80 Polymorphisms (RFLP) and allozymes to investigate genetic variation and extra-pair paternity in

81 snow petrel as well as some other Procellariiforms (Jouventin and Viot, 1985; Viot, Jouventin \&

82 Bried, 1993; Lorensten et al., 2000, Quillfeldt et al., 2001) in Antarctica.

83 As part of the 'Biology and Environmental Sciences' component of the Indian Antarctic Program,

84 we conducted comprehensive ecological surveys between 2009-2016 to understand seabird and

85 marine mammal ecology around the Indian Antarctic research stations (Pande et al. 2017).

86 Currently this programme is focused on generating baseline genetic data of breeding seabird

87 species found around Indian area of operations in Antarctica, especially on snow petrel Pagodroma

88 nivea and Wilson's storm petrel Oceanites oceanicus. The snow petrel is endemic to Antarctica

89 and Southern Ocean with breeding distribution along Antarctic coast including some inland

90 mountains and few sub-Antarctic islands (Croxall et al., 1995). On the other hand, the Wilson's

91 storm petrel has a much wider breeding distribution from Cape Horn to the Kerguelen Islands and

92 coastal Antarctica and migrates to the mid-latitudes of the north Atlantic, north Indian and Pacific

93 Oceans during non-breeding period (BirdLife International, 2017). Effective monitoring of these

94 species in the Indian Antarctic sector will require systematic information on their distribution,

95 current population status and genetic parameters. In this paper, we report results from cross-species 
96 screening of microsatellite markers for individual identification of snow petrel and Wilson's storm

97 petrel in Antarctica. These tested microsatellite panels will provide valuable tools for estimating

98 levels of genetic variation, relatedness, and genetic signals of population demography, in both

99 species across their ranges.

100 METHODS

101 Study Area

102 We carried out sampling at Larsemann Hills, Prydz Bay and Schirmacher Oasis, Central Dronning

103 Maudland (Figure 1); close to permanent Indian research stations in Antarctica Bharati

104 (Larsemann Hills) and Maitri (Schirmacher Oasis). Distance between these two study areas is

105 about 2,500 km. Larsemann Hills $\left(69^{\circ} 20^{\prime} \mathrm{S}\right.$ to $69^{\circ} 30^{\prime} \mathrm{S} ; 7^{\circ} 55^{\prime} \mathrm{E}$ to $\left.76^{\circ} 30^{\prime} \mathrm{E}\right)$, are a group of

106 islands in Prydz Bay located on the Ingrid Christensen Coast, Princess Elizabeth Land of east

107 Antarctica. This island group comprises of variously sized islands and peninsulas, located halfway

108 between the eastern extremity of the Amery Ice Shelf and the southern boundary of the Vestfold

109 Hills. Schirmacher Oasis, Central Dronning Maudland ( $70^{\circ} 44^{\prime}$ to $70^{\circ} 46^{\prime} \mathrm{S}$ and $11^{\circ} 22^{\prime}$ to $11^{\circ} 54^{\prime}$

110 E) is situated on the Princess Astrid coast about $120 \mathrm{~km}$ from the Fimbul ice shelf. Four species of

111 seabirds (Adelie penguin Pygoscelis adeliae, southpolar skua Stercorarius maccormickii, snow

112 petrel and Wilson's storm petrel) breed in the ice-free areas of Larsemann Hills whereas only the

113 south polar skua breeds at Schirmacher Oasis (Pande et al. 2017).

\section{Field Sampling}

115 We conducted sampling for this study as part of the 'Antarctic Wildlife Monitoring Programme'

116 under the Indian Scientific Expedition to Antarctica (Expedition nos. 33, 34 and 35)' during the

117 austral summers (November-March) of 2013-14, 2014-15 and 2015-16. We adopted an 
118 opportunistic genetic sampling approach under the seabird nest monitoring protocol (see Pande et

119 al., 2017) for snow petrel sample collection. First, we selected previously marked nest sites with

120 breeding snow petrel individuals for genetic sampling. Subsequently, we conducted both non-

121 destructive (buccal swabs and blood smears) and non-invasive (hatched eggshells and abandoned

122 eggs) sampling to collect biological materials from the monitored nesting sites. During non-

123 destructive sampling of snow petrel individuals, we carefully hand-captured birds at their nest

124 cavities and collected buccal swabs or blood samples. We collected blood samples from bird's

125 brachial vein using $0.1 \mathrm{ml}$ sterilized syringe needles and stored in EDTA vacutainer tubes. We

126 collected buccal epithelial tissue by gently rotating a sterilized cotton-tipped swab against the inner

127 cheek of the bird (Handel et al., 2006). All individuals were released within 60 seconds of capture.

128 Wherever available, we also collected hatched eggshells, shed adult feathers and abandoned eggs

129 from the nests. In addition, we also conducted opportunistic muscle tissue sampling of snow petrel

130 carcasses from wherever they were found. These carcasses were mostly from birds predated by

131 south polar skua or found naturally dead due to other unidentified causes. We did not find any

132 nesting sites of snow petrels at Schirmacher Oasis during our field surveys, and thus opportunistic

133 sampling of carcasses for muscle tissue was conducted.

134 Similarly, we collected Wilson's storm petrel samples from monitored nesting sites at Larsemann

135 Hills. All genetic samples of Wilson's storm petrel were collected opportunistically through

136 carcass muscle tissue collection as capturing them was not possible due to their narrow nest

137 cavities. No Wilson's storm petrel samples were collected from Schirmacher Oasis. We stored the

138 samples collected at field sites at $-20^{\circ} \mathrm{C}$ at respective Indian Antarctic research stations before

139 being brought to Wildlife Institute of India, Dehradun for further laboratory analysis. The details

140 of sampling locations are provided in Supplementary File 1. 
141

142

143

144

145

146

147

148

149

150

151

152

153

154

155

156

157

158

159

160

161

162

\section{Primer selection}

As there are no species-specific microsatellite markers published for snow petrel, we screened a panel of cross-species markers for individual identification of snow petrels. We selected 15 microsatellite markers developed for Hawaiian petrel Pterodroma sandwichensis (Nine markers, Welch and Fleischer 2011) and white-chinned petrel Procellaria aequinoctialis (Six markers, Techow and O'Ryan 2004). These markers were selected based on their polymorphic information content (number of alleles as well as expected heterozygosity) in the aforementioned species. We also tested this panel of 15 microsatellite loci for individual identification of Wilson's Storm Petrel samples.

\section{DNA extraction and primer standardization}

We used muscle tissue samples of snow petrel and Wilson's storm petrel for initial standardization and validation of microsatellite panel. Genomic DNA was extracted in duplicate from all tissue samples using commercially available DNeasy Tissue kit (QIAGEN Inc.) using a modified approach. In brief, all samples were macerated with sterile blades independently, followed by overnight complete tissue digestion with $25 \mu \mathrm{l}$ proteinase-K. Post-digestion, extraction was performed using Qiagen animal tissue spin column protocol. DNA was eluted twice with $100 \mu \mathrm{L}$ of $1 \mathrm{X}$ TE and stored in $-20^{\circ} \mathrm{C}$ until further processing. Each set of 11 extractions was accompanied with one extraction control to monitor possible contamination.

We conducted all initial PCR standardizations using muscle tissue DNA samples. We carried out amplifications for each primer in $10 \mu \mathrm{L}$ reaction volumes containing $4 \mu \mathrm{L}$ Qiagen Multiplex PCR buffer mix (Qiagen Inc.), $0.2 \mu \mathrm{M}$ labeled forward primer, $0.2 \mu \mathrm{M}$ reverse primer, $4 \mu \mathrm{M}$ BSA and $2 \mu \mathrm{L}$ of 1:10 diluted DNA extract. The temperature regime included an initial denaturation $\left(94{ }^{\circ} \mathrm{C}\right.$ 
163 for $15 \mathrm{~min})$; 35 cycles of denaturation $\left(94{ }^{\circ} \mathrm{C}\right.$ for 30 seconds), annealing (53 or $57{ }^{\circ} \mathrm{C}$ for 45

164 seconds) and extension $\left(72{ }^{\circ} \mathrm{C}\right.$ for 45 seconds); followed by a final extension ( $72{ }^{\circ} \mathrm{C}$ for $\left.30 \mathrm{~min}\right)$.

165 Post-temperature standardization, primers with identical annealing temperatures was optimized for

166 multiplex reactions with the same samples of both species (see Table 1). Subsequently, all test

167 samples were amplified with standardized parameters. During all amplifications, both extraction

168 controls and PCR negative controls (one PCR negative every set of amplifications) were included

169 to monitor any possible contamination. PCR products were visualized in $2 \%$ agarose gels, and

170 genotyped using LIZ500 size standard in an automated ABI3500XL genetic analyzer.

171 Microsatellite alleles were scored using program GENEMARKER (SOFTGENETICS Inc.) and

172 allele bins for each locus were created from the data generated. We randomly re-genotyped 15\%

173 of each locus from different samples to check for reliable genotypes and estimated genotyping

174 error rates.

175 Data analysis

176 We calculated average amplification success as the percent positive PCR for each locus, as 177 described by Broquet, Ménard \& Petit (2007). We quantified allelic dropout and false allele rates 178 manually as the number of dropouts or false alleles over the total number of amplifications, 179 respectively (Broquet, Ménard \& Petit,. 2007). We also calculated the Probability of Identity for 180 siblings $\left(\mathrm{PID}_{\text {sibs }}\right)$, the probability of two individuals drawn from a population sharing the same 181 genotype at multiple loci and the theoretical Probability of Identity or PID unbiased (Waits, Taberlet 182 \& Luikart, 2001) using program GIMLET (Valière, 2002). We tested the frequency of null alleles 183 in our data set using FREENA (Chapuis \& Estoup, 2007) whereas summary statistics, tests for 184 deviations from Hardy-Weinberg equilibrium and pairwise linkage disequilibrium were calculated 185 for each locus using program ARLEQUIN v.3.1 (Excoffier, Guillaume \& Schneider, 2005). 


\section{Results and discussion}

187 We genotyped a total of 55 snow petrel and 24 Wilson's storm petrel samples to test and 188 standardize the selected microsatellite markers. Snow petrel samples were selected from blood (n $189=1)$, buccal swab $(n=2)$, carcass muscle tissue $(n=24)$ and hatched eggshells $(n=28)$ to test 190 amplification success from different types of biological samples. Wilson's storm petrel samples 191 were all from muscle tissue of individual carcasses collected in the field.

192 Of the 15 loci tested during the initial standardization, 12 loci showed amplification for snow petrel 193 (loci Ptero2, Ptero6 and Ptero10 did not amplify), whereas only 10 loci successfully amplified for

194 Wilson's storm petrel (loci Paequ2, Ptero2, Ptero6, Ptero8 and Ptero10 did not amplify) (Table 1). 195 Subsequently, these panels of 12 and 10 loci were tested with all snow petrel and Wilson's storm petrel samples, respectively. Overall, the amplification success ranged between $96.4-100 \%$ for snow petrel and 91.7 - 100\% for Wilson's storm petrel; and allelic dropout rates were $0-3.6 \%$ and $0-8.3 \%$ for snow petrel and Wilson's storm petrel respectively (see Table 1 for more details). For snow petrel, the loci varied from highly polymorphic (Paequ03- 12 alleles, $\mathrm{H}_{0}-0.68$ ) to less polymorphic (Paequ13- 4 alleles, $\mathrm{H}_{\mathrm{o}^{-}}$0.07), whereas for Wilson's storm petrel the loci were moderately polymorphic (Ptero07- 6 alleles, $\mathrm{H}_{\mathrm{o}}$ - 0.76) to less polymorphic (Paequ13- 2 alleles, $\mathrm{H}_{\mathrm{o}^{-}}$0.08) (Table 1). Two loci in snow petrel (Ptero01 and Ptero09) and three loci in Wilson's storm petrel (Ptero04, Ptero09 and Paequ07) were found to deviate from the Hardy-Weinberg Equilibrium, and thus were removed from any further analysis. There was no evidence for a strong linkage disequilibrium between any pair of loci (details in Supplementary Files 2 and 3). PID sibs $_{\text {s }}$ and $\mathrm{PID}_{\text {unbiased }}$ values were found to be $3.71 \times 10^{-03}$ and $8.89 \times 10^{-07}$ for snow petrel, and $1.94 \mathrm{x}$

$20710^{-02}$ and $9.25 \times 10^{-05}$ for WSP, respectively. Locus-wise and average values for observed and expected heterozygosity, number of alleles and allelic size ranges are presented in Table 1 . The 
209 frequency of null alleles across the loci was observed to be low in both the study species (snow

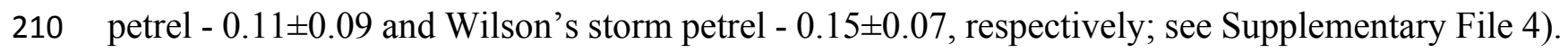

211 This paper is the first attempt to use nuclear microsatellite markers to individually identify both 212 snow petrel and Wilson's storm petrel in Antarctica, and the final panel described here provide 213 unambiguous individual identification from both species in our study area. Testing the markers on 214 various types of biological materials (tissue, blood, buccal swab and hatched eggshells) showed 215 high amplification success, but further tests with non-invasive samples (for example, shed 216 feathers) is required for long-term studies. Both $\mathrm{PID}_{\text {unbiased }}$ and $\mathrm{PID}_{\text {sibs }}$ values are also sufficient 217 enough for population genetic studies considering low population sizes of snow petrel (800-1000 218 individuals) and Wilson's storm petrel (<200 individuals) in the study area (Pande et al. 2017, 219 Pande et al. unpublished report). However, it is important to point out that in case of Wilson's 220 storm petrel the $\mathrm{PID}_{\text {sibs }}$ value of $1.9 \times 10^{-2}$ may not be sufficiently robust enough for large 221 populations based on suggestions of earlier studies (Waits et al., 2001; Miller et al., 2005), where

222 such low value could potentially lead to higher misidentification rates. Future studies should 223 consider testing additional cross-specific markers previously developed for prion species 224 (Pachyptila sp.) but also tested in Wilson's storm petrel (Moodley et al. 2015) to create a 225 comprehensive panel for studying large populations of the species.

\section{Conclusion}

227 Molecular genetic analysis has become crucial in understanding levels of genetic differentiation, 228 hybridisation and extinction risk in seabird populations (Taylor and Friesen, 2012). In critical 229 ecosystems such as Antarctica, individual-level genetic data can be a valuable tool to study 230 evolution, adaptation, past events of diversifications and extinctions for wide-ranging seabirds.

231 Moreover, genetic datasets on species of pelagic seabirds such as snow petrel and Wilson's storm 
232 petrel are generally lacking in comparison with charismatic species such as penguins. In this study,

233 we could establish the efficacy of cross-species markers in individual identification of these two

234 common Antarctic seabird species. In the future, we aim to build upon the long-term genetic

235 research under the 'Antarctica Wildlife Monitoring Programme' by increasing spatio-temporal

236 sampling efforts to understand the population structure, relatedness and other aspects and provide

237 insights to seabird behaviour (monogamy, extra-pair paternity etc.) and evolution. This detailed

238 genetic research will also aid in long-term ecological monitoring and conservation management of

239 breeding seabird populations of Antarctica.

\section{Permits and ethical clearances}

241 All samples were collected under the 'Biology and Environmental Sciences' component (Letter

242 no: NCAOR/ANT/ASPA/2014-15/01) of the Indian Scientific Expeditions to Antarctica with

243 appropriate approvals from the Environment Officer, Committee for Environmental Protection

244 (Antarctic Treaty Secretariat), National Centre for Antarctic and Ocean Research, Earth System

245 Science Organisation, Ministry of Earth Sciences, Government of India, Goa, India.

\section{Acknowledgements}

247 We thank the National Centre for Antarctic and Ocean Research, Ministry of Earth Sciences for 248 providing all logistic support during the Indian Scientific Expeditions to Antarctica. We are 249 grateful to respective expedition leaders and team member volunteers of $33^{\text {rd }}, 34^{\text {th }} \& 35^{\text {th }}$ Indian

250 Scientific Expeditions to Antarctica for their assistance during field work. We thank A. Madhanraj, 251 and MEERCAT lab members for their help in laboratory and Srinivas for his inputs on data 252 analysis. We sincerely thank Wildlife Forensics and Conservation Genetics Cell, CAMPA Cell, 
253 Research Coordinator and Dean, Wildlife Institute of India for their support. Our sincere thanks to

254 all the reviewers of the earlier version of manuscript.

255 Figure legend

256 Figure 1: Seabird sampling locations in Antarctica. A) Schirmacher oasis, site of Maitri station B)

257 Larsemann hills, site of Bharati station (Photo Credit: Anant Pande).

258 Table legend

259 Table 1:

260 Characterization of microsatellite loci genotyped in a) Snow Petrel and b) Wilsons's Storm Petrel

261 individual samples from Antarctica

262

263

264

265

266

267

268

269

270

271

272

273

274

275

276

277

278

279

280

281

282

283

284

\section{References}

- Barbraud C, Weimerskirch H. 2001. Contrasting effects of the extent of sea-ice on the breeding performance of an Antarctic top predator, the snow petrel Pagodroma nivea. Journal of Avian Biology 32: 297-302.

- Barbraud C, Weimerskirch H. 2006. Antarctic birds breed later in response to climate change. Proceedings of the National Academy of Sciences of the United States of America 103: 6248-51.

- BirdLife International. 2017. Species factsheet: Oceanites oceanicus. Available at http://datazone.birdlife.org/species/factsheet/22698436 (accessed 17 November 2017).

- Broquet T, Ménard N, Petit E. 2007. Noninvasive population genetics: A review of sample source, diet, fragment length and microsatellite motif effects on amplification success and genotyping error rates. Conservation Genetics 8: 249-260.

- Brown RM, Techow NMSM, Wood AG, Phillips, RA. 2015. Hybridization and backCrossing in giant petrels (Macronectes giganteus and M. halli) at Bird Island, South Georgia, and a summary of hybridization in seabirds. Plos One, 10: e0121688. DOI: 10.1371/journal.pone.0121688.

- Chapuis MP, Estoup A. 2007. Microsatellite null alleles and estimation of population differentiation. Molecular Biology and Evolution 24: 621-631.

- Croxall JP, Steele WK, McInnes SJ, Prince PA. 1995. Breeding distribution of the snow petrel Pagodroma nivea. Marine Ornithology 23: 69-99.

- Croxall JP, Butchart SHM, Lascelles B, Stattersfield AJ, Sullivan B, Symes A, Taylor P. 2012. Seabird conservation status, threats and priority actions : a global assessment. Bird Conservation International 22: 1-34. 
- Excoffier L, Guillaume L, Schneider S. 2005. Arlequin (version 3.0): An integrated software package for population genetics data analysis. Evolutionary Bioinformatics Online 1: 47-50.

- Gómez-Díaz E, González-Solís J, Peinado MA. 2009. Population structure in a highly pelagic seabird, the Cory's shearwater Calonectris diomedea: An examination of genetics, morphology and ecology. Marine Ecology Progress Series 382:197-209.

- Handel CM, Pajot LM, Talbot SL, Sage GK. 2006. Use of buccal swabs for sampling DNA from nestling and adult birds. Wildlife Society Bulletin 34(4): 1094-1100.

- Jouventin P, Viot CR. 1985. Morphological and genetic variability of Snow Petrels Pagodroma nivea. Ibis 127: 430-441.

- Lascelles BG, Langham GM, Ronconi RA, Reid JB. 2012. From hotspots to site protection: Identifying Marine Protected Areas for seabirds around the globe. Biological Conservation 156: 5-14.

- Lorensten S, Amundsen T, Anthonisen K, Lifjeld J. 2000. Molecular evidence for extrapair paternity and female-female pairs in Antarctic Petrels. The Auk, 117:1042-1047.

- Miller CR., Joyce P, Waits LP. 2005. A new method for estimating the size of small populations from genetic mark-recapture data. Molecular ecology 14(7): 1991-2005.

- Moodley Y, Masello JF, Cole TL, Calderon L, Munimanda GK, Thali MR, Alderman R, Cuthbert RJ, Marin M, Massaro M, Navarro J, Phillips RA, Ryan PG, Suazo CG, Cherel Y, Weimerskirch H, Quillfeldt P. 2015. Evolutionary factors affecting the cross-species utility of newly developed microsatellite markers in seabirds. Molecular Ecology Resources 15: 1046-1058 DOI: 10.1111/1755-0998.12372

- Nunn GB, Stanley SE. 1998. Body size effects and rates of cytochrome b evolution in tubenosed seabirds. Molecular Biology and Evolution 15: 1360-1371.

- Paleczny M, Hammill E, Karpouzi V, Pauly D. 2015. Population trend of the World's monitored seabirds, 1950-2010. Plos One 10:e129342.

DOI: 10.1371/journal.pone.0129342.

- Pande A, Sivakumar K, Sathyakumar S, Kumar RS, Johnson JA, Mondol S, Mathur VB. 2017. Monitoring wildlife and their habitats in the Southern Ocean and around Indian research stations in Antarctica. Proceedings of the Indian National Science Academy 83: 483-496.

- Piatt JF, Sydeman WJ, Wiese F. 2007. Introduction: A modern role for seabirds as indicators. Marine Ecology Progress Series 352: 199-204.

- Quillfeldt P, Moodley Y, Weimerskirch H, Cherel Y, Delord K, Phillips RA, Navarro J, Calderón L, Masello JF. 2017. Does genetic structure reflect differences in non-breeding movements? A case study in small, highly mobile seabirds. BMC Evolutionary Biology 17: 1-11.

- Quillfeldt P, Schmoll T, Peter HU, Epplen JT, Lubjuhn T. 2001. Genetic Monogamy in Wilson's storm-petrel. The Auk 118:242.

- Taylor SA, Friesen VL. 2012. Use of molecular genetics for understanding seabird evolution, ecology and conservation. Marine Ecology Progress Series 451: 285-304. 
326

327

328

329

330

331

332

333

334

335

336

337

338

339

340

341

342

343

344

345

346

347

- Techow, NMSM, O'Ryan C. 2004. Characterization of microsatellite loci in Whitechinned petrel (Procellaria aequinoctialis) and cross-amplification in six other procellariiform species. Molecular Ecology Notes 4: 33-35.

- Techow NMSM, O'Ryan C, Phillips RA, Gales R, Marin M, Patterson-Fraser D, Quintana F, Ritz MS, Thompson DR, Wanless RM, Weimerskirch H, Ryan PG. 2010. Speciation and phylogeography of giant petrels Macronectes. Molecular Phylogenetics and Evolution 54: 472-487.

- Valière, N. 2002. GIMLET: a computer program for analysing genetic individual identification data. Molecular Ecology Notes 2: 377-379.

- Viot CR, Jouventin P, Bried J. 1993. Population genetics of southern seabirds. Marine Ornithology 21: 1-5.

- Waits L, Taberlet P, Luikart G. 2001. Estimating the probability of identity among genotypes in natural populations: cautions and guidelines. Molecular Ecology 10: 249256.

- Warham J. 1996. The behaviour, population biology and physiology of the Petrels. Academic Press.

- Welch AJ, Fleischer RC. 2011. Polymorphic microsatellite markers for the endangered Hawaiian Petrel (Pterodroma sandwichensis). Conservation Genetics Resources 3: 581584. DOI:10.1007/s12686-011-9409-4

- Welch AJ, Fleischer RC, James HF, Wile AE, Ostrom PH, Adams J, Duvall F, Holmes N, $\mathrm{Hu}$ D, Penniman J, Swindle KA. 2012. Population divergence and gene flow in an endangered and highly mobile seabird. Heredity 109: 19-28 DOI:10.1038/hdy.2012.7. 


\section{Table 1 (on next page)}

Characterization of microsatellite loci genotyped in snow petrel and Wilsons's storm petrel individuals from Antarctica 


\section{Table 1. Characterization of microsatellite loci genotyped in a) Snow Petrel and b) Wilsons's Storm Petrel individual samples from Antarctica}

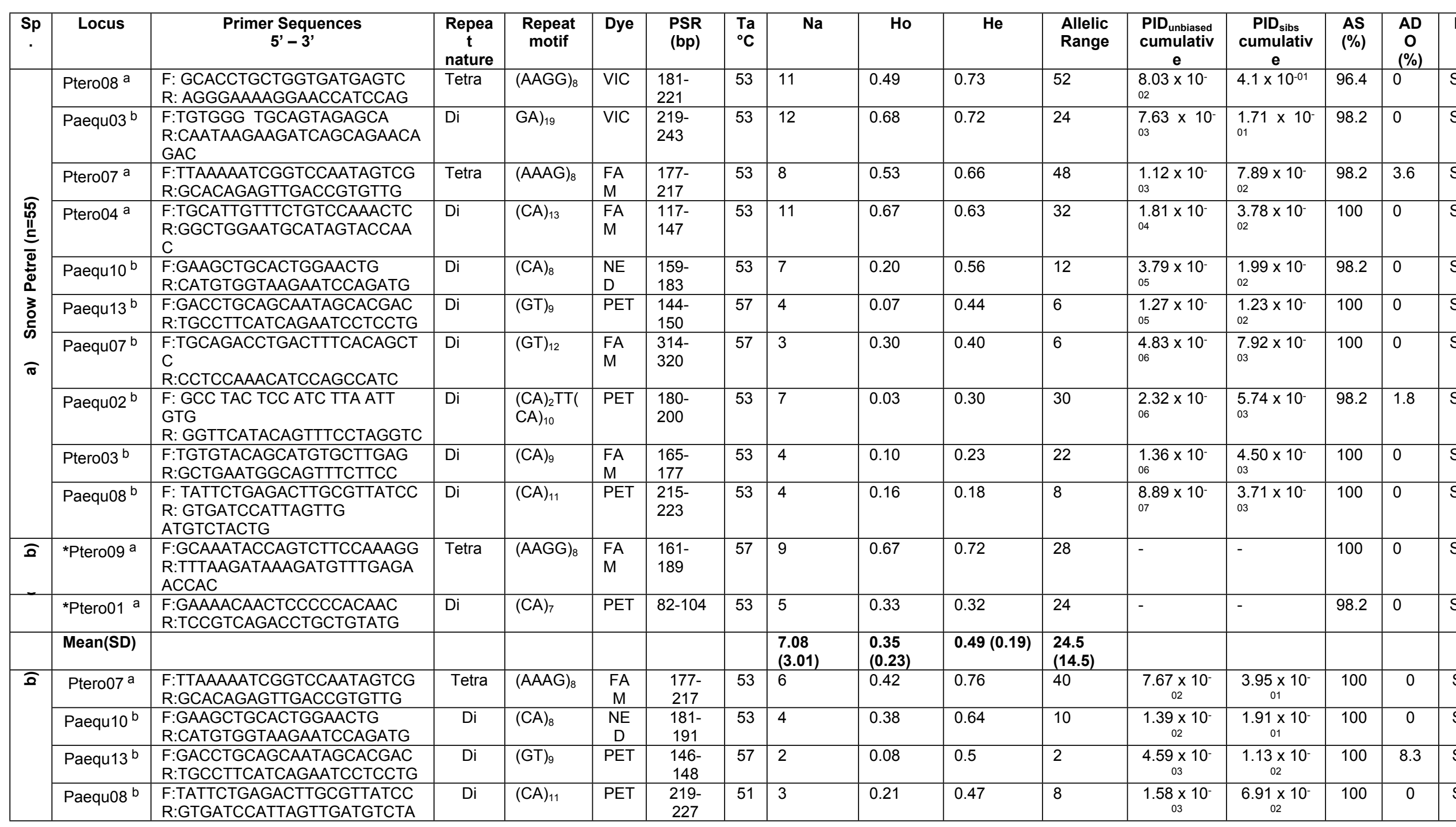




\begin{tabular}{|c|c|c|c|c|c|c|c|c|c|c|c|c|c|c|}
\hline & CTG & & & & & & & & & & & & & \\
\hline Ptero0 $1^{a}$ & $\begin{array}{l}\text { F:GAAAACAACTCCCCCACAAC } \\
\text { R:TCCGTCAGACCTGCTGTATG }\end{array}$ & $\mathrm{Di}$ & $(\mathrm{CA})_{7}$ & PET & $\begin{array}{l}165- \\
177\end{array}$ & 53 & 4 & 0.17 & 0.44 & 12 & $\begin{array}{c}5.56 \times 10^{-} \\
04\end{array}$ & $\begin{array}{c}4.28 \times 10^{-} \\
02\end{array}$ & 100 & 0 \\
\hline Paequ03 b & $\begin{array}{l}\text { F: TGTGGGTGCAGTAGAGCA } \\
\text { R: } \\
\text { CAATAAGAAGATCAGCAGAACAG } \\
\text { AC }\end{array}$ & $\mathrm{Di}$ & $(\mathrm{GA})_{19}$ & VIC & $\begin{array}{l}219- \\
235\end{array}$ & 53 & 5 & 0.21 & 0.39 & 16 & $\begin{array}{c}2.04 \times 10^{-} \\
04\end{array}$ & $\begin{array}{c}2.79 \times 10^{-} \\
02\end{array}$ & 100 & 0 \\
\hline Ptero03 $^{a}$ & $\begin{array}{l}\text { F:TGTGTACAGCATGTGCTTGAG } \\
\text { R:GCTGAATGGCAGTTTCTTCC }\end{array}$ & $\mathrm{Di}$ & $(\mathrm{CA})_{9}$ & $\begin{array}{l}\text { FA } \\
M\end{array}$ & $88-104$ & 57 & 2 & 0.17 & 0.35 & 16 & $\begin{array}{c}9.25 \times 10^{-} \\
05\end{array}$ & $\begin{array}{l}1.94 \times 10^{-} \\
02\end{array}$ & 91.7 & 0 \\
\hline${ }^{*}$ Paequ07 ${ }^{b}$ & $\begin{array}{l}\text { F:TGCAGACCTGACTTTCACAGCT } \\
\text { C } \\
\text { R:CCTCCAAACATCCAGCCATC }\end{array}$ & $\mathrm{Di}$ & $(\mathrm{GT})_{12}$ & $\begin{array}{l}\text { FA } \\
M\end{array}$ & $\begin{array}{l}312- \\
318\end{array}$ & 51 & 3 & 0.08 & 0.16 & 6 & - & - & 100 & 4.2 \\
\hline${ }^{*}$ Ptero09 ${ }^{a}$ & $\begin{array}{l}\text { F: } \\
\text { GCAAATACCAGTCTTCCAAAGG } \\
\text { R:TTTAAGATAAAGATGTTTGAGA } \\
\text { ACCAC }\end{array}$ & Tetra & $(\mathrm{AAGG})_{8}$ & $\begin{array}{l}\text { FA } \\
M\end{array}$ & $\begin{array}{l}173- \\
185\end{array}$ & 61 & 6 & 0.67 & 0.55 & 16 & - & - & 91.7 & 0 \\
\hline${ }^{*}$ Ptero04 ${ }^{a}$ & $\begin{array}{l}\text { F:TGCATTGTTTCTGTCCAAACTC } \\
\text { R:GGCTGGAATGCATAGTACCAA } \\
\text { C }\end{array}$ & $\mathrm{Di}$ & $(\mathrm{CA})_{13}$ & $\begin{array}{l}\text { FA } \\
M\end{array}$ & $\begin{array}{l}127- \\
139\end{array}$ & 57 & 4 & 0.38 & 0.52 & 12 & - & - & 100 & 0 \\
\hline Mean(SD) & & & & & & & $3.9(1.3)$ & $\begin{array}{l}0.28(0.1 \\
8)\end{array}$ & $0.48(0.15)$ & $\begin{array}{l}13.8 \\
(9.7)\end{array}$ & & & & \\
\hline
\end{tabular}




\section{Figure 1}

Seabird sampling locations in Antarctica.

A) Schirmacher oasis, site of Maitri station B) Larsemann hills, site of Bharati station (Photo Credit: Anant Pande).

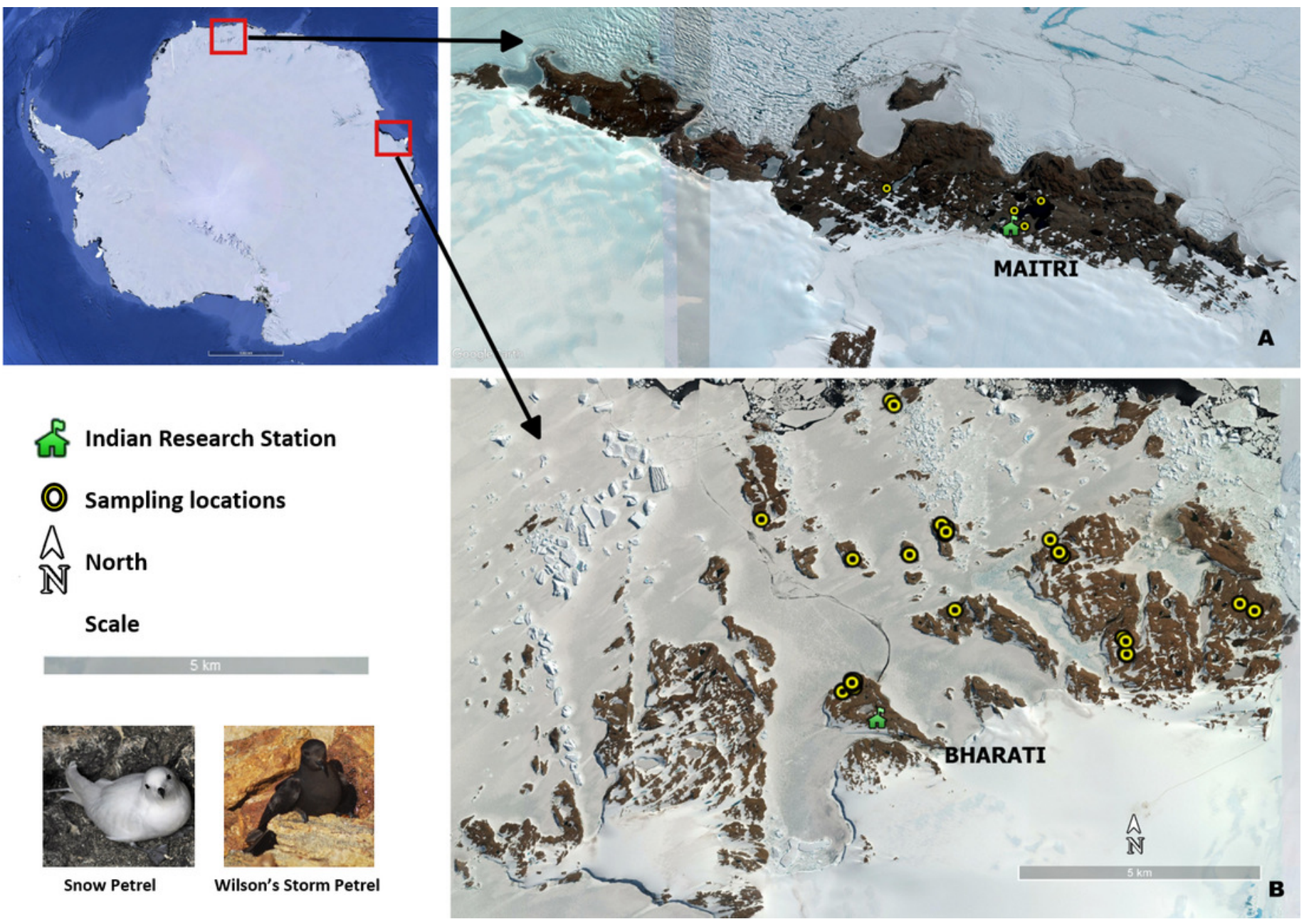

